Дергачова В.В.

доктор. економ. наук, професор ORCID ID: 0000-0003-0317-8675

Колешня Я.О.

ORCID ID: 0000-0002-4856-4898

Національний технічний університет Украӥни

«Київський політехнічний інститут імені Ігоря Сікорського»

\title{
ВПЛИВ СУЧАСНИХ ІНФОРМАЦІЙНИХ ТЕХНОЛОГІЙ НА ЕКОНОМІЧНУ БЕЗПЕКУ ПІДПРИЕМСТВА
}

\section{ВЛИЯНИЕ СОВРЕМЕННЫХ ИНФОРМАЦИОННЫХ ТЕХНОЛОГИЙ НА ЭКОНОМИЧЕСКУЮ БЕЗОПАСНОСТЬ ПРЕДПРИЯТИЯ}

\section{THE INFLUENCE OFMODERN INFORMATION TECHNOLOGIES ON ECONOMIC SECURITY OF ENTERPRISE}

У статті розглядається вплив сучасних інформачійних технологій на діяльність підприємства, як позитивного так $і$ негативного. Водночас демонструється масштаб їх проникнення у всі сфери життя, $i$ в тому числі бізнес, як у B2C, так $і$ в B2B-сектор.

У статті описуються практичні приклади використання сучасних інформачійних технологій, щу покликані підвищити ефективність діяльності підприємства та збільшити його конкурентоздатність на сучасному динамічному ринку. Серед них можна виділити такі, як сloud сотриting, віртуальні підприємства, онлайн-підприємства, електронний документообіг, програми по складанню бізнес-планів тощо. Окремо розглядається використання хмарних технологій у діяльності бізнес-одиниць, як технологї̈, щуо набуває активного поширення.

Доведено, щзо сучасні технологї̈, починаючи від програм обміну інформацією, закінчуючи використанням харних технологій, несуть відчутний вплив не лише на інформаційну, а й на всі складові економічної безпеки. Залежно від того, чи зможе підприємство використати можливості, щзо перед ним виникають $i$ чи зможе протистояти новим загрозам, визначається його можливість зберігати високий рівень економічної безпеки. Стаття систематизує вплив інформаційних технологій за окремими складовими економічної безпеки, розглядаючи як позитивні, так і негативні його наслідки.

Ключові слова: інформаційні технологї, хмарні технологї, проникнення інформачійних технологій, інформачийна безпека.

B статье рассматривается влияние современных информачионных технологий на деятельность предприятия, как положительное так и отрицательное. В то же время демонстрируется масштаб их проникновения во все сферы жизни, и в том числе бизнес, как в В2C, так и в В2B-секторе.

В статье описываются практические примеры использования современных информационных технологий, которые призваны повысить эффективность деятельности предприятия и увеличить его конкурентоспособность на современном динамичном рынке. Среди них можно выделить такие, как - cloud coтputing, виртуальные предприятия, онлайн-предприятия, электронный документооборот, программы по составлению бизнес- 
планов и т.п. Отдельно рассматривается использование облачных технологий в деятельности бизнес-единии, как технологии, которая приобретает активное распространение.

Доказано, что современные технологии, начиная от программ обмена информацией, заканчивая использованием облачных технологий, оказывают ощутимое влияние не только на информационную, но и на все составляюшие экономической безопасности. В зависимости от того, сможет ли предприятие использовать возможности, которые возникают и сможет ли противостоять новым угрозам, определяется его возможность сохранять высокий уровень экономической безопасности. Статья систематизирует влияние информационных технологий по отдельным составляющим экономической безопасности, рассматривая как положительные, так $и$ отрицательные их последствия.

Ключевые слова: информачионные технологии, облачные технологии, проникновение информационных технологий, информационная безопасность.

The article is considered with the influence of modern information technology on the business, both positive and negative. At the same time it demonstrates the scale of their penetration into all areas of life, including business, both in B2C, and in the B2B-sector.

The article describes practical examples of the use of modern information technologies that are designed to increase the efficiency of the company and increase its competitiveness in today's dynamic market. Among them are such as - Cloud computing, virtual enterprises, online businesses, electronic documents, applications for assembly business plans and so on. Separately considered the use of cloud technologies in business units, as a technology that becomes active disseminated.

It is proved that modern technologies, ranging from information exchange programs, ending the use of Cloud technologies have a significant impact not only on information but also on all the components of economic security. Depending on whether the enterprise can use the opportunities that arise and whether it will be able to withstand new threats, its ability to maintain a high level of economic security is determined. Article codifies the impact of information technology on the individual components of economic security, considering both positive and negative effects of it.

Keywords: information technology, cloud technology, the penetration of information technology, information security.

Вступ. Нові технології все глибше і глибше проникають не лише у побутове життя людей, але і в різні сфери бізнесу. Вже стало цілком звичним здійснювати покупки через Інтернет, одразу ж їх оплачуючи; здійснювати пошук найрізноманітнішої інформації, користуватися різноманітними програмами, що допомагають контролювати та планувати бюджет тощо. При чому ця тенденція стосується не лише В2С сфери, а й В2В - все більше і більше підприємств переводять свою роботу в онлайн-режим, застосовують нові інформаційні технології. Зрозуміло, що це не може не впливати на формування економічної безпеки підприємств. Здебільшого, такий вплив розглядається лише з точки зору інформації (та, відповідно, інформаційної безпеки), як, наприклад, у Каркавчука В. та Чурчука А. [1]; або можливості здійснювати автоматизоване управління підприємствами (Орлик О.В. [2]). 
Роль інформаційних технологій набагато ширше досліджується представниками бізнесу (Рудковський О. [3]). Проте, на нашу думку, напрями впливу інформаційних технологій на сьогодні набагато ширші, а тому потребують детального вивчення.

Постановка завдання. Інформаційні технології широко проникають в усі сфери діяльності людей і бізнес не є виключенням. Підприємницька діяльність сьогодні тісно пов'язана 3 використанням нового програмного забезпечення, комп'ютерних систем і технологій, нового інформаційного середовища та нових можливостей (як, наприклад, цифровий обмін документами чи використання цифрового підпису). Проте доволі часто інформаційні технології сприяють формуванню і нових загроз, що діючи на окремі складові системи економічної безпеки підприємства, можуть знижувати рівень економічної безпеки в цілому.

Тому завданням даної статті є вивчення та систематизація напрямків впливу сучасних інформаційних технологій на економічну безпеку підприємства шляхом.

Методологія. Основним методом, застосованим у роботі $\epsilon$ аналіз існуючих теоретичних положень щодо впливу інформаційних технологій на діяльність підприємств; збір та узагальнення інформації щодо існуючих інформаційних технологій, що сьогодні можуть використовуватися підприємства різних сфер діяльності; а також систематизація напрямків впливу інформаційних технологій на діяльність підприємства та його економічну безпеку.

Результати дослідження. Роль інформаційних технологій сьогодні дуже складно переоцінити. Вони беруть участь в управлінні, обліку, плануванні, обміні інформацією - на будь-якому підприємстві будь-якої галузі - від використання програм обліку (1С.Бухгалтерія, 1С.Підприємство, Парус) чи обміну податковими накладними (MeDoc) до переведення функціонування бізнесу майже в повністю автоматичний режим (наприклад, Інтернетмагазини, де всі етапи покупки товару проходять виключно онлайн).

Це створює нові можливості для бізнесу, проте поряд з тим виникають i нові загрози. І відповідно до цього, підприємства повинні формувати нові можливості для протистояння цим загрозам та зберігати свою економічну безпеку. А тому важливо систематизувати вплив сучасних інформаційних технологій на діяльність підприємства за окремими складовими економічної безпеки.

Першою перевагою інформаційних технологій є швидкий доступ до інформації. Сьогодні знайти відповідь на будь-яке питання можна за кілька хвилин - від курсу валют до вартості, наприклад, бетонного заводу. В мінливих та нестабільних умовах господарювання, коли потрібно швидко 
прийняти управлінське рішення, дуже важливо вчасно отримати та проаналізувати потрібну інформацію.

Проблемою в даному випадку $\epsilon$ те, що інформація, що поступає до керівництва, не завжди є точною чи навіть правдивою. А тому потрібно вміти ii «фільтрувати» та аналізувати, що потребує наявності у керівника відповідних здібностей та знань.

Водночас швидкість доступу до інформації тягне за собою ще одну проблему - загрозу інформаційній безпеці підприємства. Окрім того, що всі конкуренти можуть вільно отримати інформацію 3 мережі Інтернет (цінова політика, напрямки діяльності) i використовувати іiі для формування своєї діяльності на тих же основах або навіть кращих (наприклад, надання більшої знижки, ніж конкурент; вигідніших умов співпраці тощо). Особливості поведінки споживача в окремих висококонкурентних сферах не дають можливості уникнути відображення цін, умов доставки чи оплати (як, наприклад, у випадку Інтернет-магазинів), а тому конкурентна боротьба ще більше загострюється і якщо підприємство не має змоги весь час розвиватися, пропонуючи більш вигідні умови, ніж конкуренти, постає загроза втрати позиції на ринку.

Інтернет також дозволяє формувати «чисту» конкуренцію, оскільки потенційні клієнти чи працівники завжди можуть знайти відгуки про компанію i якщо в іiі діяльності $\epsilon$ недоліки - рано чи пізно кількість негативних відгуків посприяє занепаду такої компанії і іï виходу з ринку. Таким чином, Інтернет дозволяє сформувати ринок 3 надійними та перевіреними компаніями.

Сучасні технології дозволяють суттєво економити час та зусилля. Так, знайти постачальника обладнання можна просто розіславши запити потенційним постачальникам та проаналізувавши отримані комерційні пропозиції. При чому це стосується в тому числі і зарубіжних постачальників. Водночас, обравши найвигіднішу пропозицію, можна зекономити і кошти.

Полегшується і пошук персоналу - серед безлічі сайтів пошуку роботи можна швидко і без затрат знайти ряд кандидатів. Щоправда, в даному випадку може виникнути ризик «відкинути» кандидатів, які не змогли подати інформацію про себе у резюме, проте під час живого спілкування проявили б себе як хороші спеціалісти.

3 використанням Інтернету можливим стає навчання персоналу навіть без відриву від роботи - 3 допомогою вебінарів. Досить часто таке навчання $\epsilon$ безкоштовним.

Сучасні технології дають можливість суттєво розширити ринки, на котрих діє компанія - для цього не обов'язково фізично бути присутнім в тому чи іншому регіоні, відкривши там філіал чи підрозділ. Інтернет дозволяє охоплювати не лише ринок рідної країни підприємства, а й виступати 
учасником зарубіжних ринків - достатньо мати IP-телефонію, котра дає можливість підключати телефонний номер країни, де потенційно відкривається новий ринок збуту, а різноманітні програми (управління замовленнями, контроль залишків на складі, бухгалтерські програми, електронні підписи) та склади відповідального зберігання дозволяють управляти процесом реалізації продукції у віддаленому доступі. Банківські технології при цьому дозволяють отримати оплату теж у країні фізичного базування підприємства.

Так само полегшується і придбання потрібного обладнання за кордоном, уникаючи посередників, котрі встановлюють свою націнку, таким чином економляться фінансові ресурси.

Технології полегшують бізнес-планування, дозволяючи моделювати економічні процеси і таким чином прогнозувати можливі наслідки реалізації певних проектів.

Однією 3 найбільш важливих технологій, що полегшують ведення бізнесу, є «хмарна» технологія - Cloud computing, тобто віддалене зберігання та обробка даних. Вона передбачає перенесення всіх програм чи додатків на віддалений сервер (так звану «хмару»). Для доступу до цієї хмари користувачу потрібен всього лише доступ до Інтернету, логін та пароль. Такі технології дозволяють суттєво економити кошти, оскільки власнику бізнесу не потрібно розгортати власні потужності.

Переваг у таких технологій багато [3]:

- Легкість доступу. Керівник може контролювати все процеси з будьякої точки планети, маючи лише комп’ютер (або навіть смартфон) і Інтернет.

- Збереження інформації. Постачальник послуг має набагато більше можливостей (як фінансових, так і технологічних та інтелектуальних) по захисту інформації, оскільки це $\epsilon$ однією зі складових його діяльності і саме на цьому він спеціалізується.

- Економічний ефект i висока якість послуги. Розгортання інфраструктури на підприємстві обійдеться набагато дорожче, ніж використання хмарної технології. До того ж конкуренція в цій сфері стимулює до покращення якості системи, адже клієнта важливо не тільки отримати, але i втримати.

- Забезпечення спільної роботи. Підприємство працює в одному середовищі 3 багатьма контрагентами, а така система полегшує обмін інформацією, дозволяє зберігати великі масиви даних i здійснювати оперативний обмін ними у разі необхідності.

- Неможливість рейдерського захоплення бізнесу. В разі потреби його можна досить швидко згорнути чи перемістити - достатньо просто забрати 3 офісу техніку. 
Основним суб'єктом, що найбільш широко використовує хмарні технології - це малий та середній бізнес, оскільки для них економія коштів та захист інформації відіграють ключову роль. Великі підприємства більш схильні формувати лише власні, внутрішні мережі. За оцінками спеціалістів, перехід на хмарні технології дозволяє скоротити витрати на 20\% [4].

Деякі автори говорять про створення так званих віртуальних підприємств [5, с. 152-153], які являють собою групу підприємств, що працюють в спільному інформаційному просторі над виконанням одного завдання (іноді це - виконання індивідуального замовлення клієнта), але при цьому вони можуть знаходитися в різних містах, країнах чи континентах. Така система співпраці формує можливості по виконанню практичного будь-якого замовлення з метою задоволення потреби кожного конкретного споживача продукції чи послуги, адже навіть у випадку, коли фірма стикається 3 проблемою, вона завжди може перенести певний етап створення продукту чи послуги на партнера. Розвиток інформаційних систем дозволяє швидко знайти виконавця, передати технічне завдання і вирішити всі організаційні питання, а розвиненість логістичних мереж - швидко передати готову частину продукту на наступний етап.

Серед групи підприємств обов'язково завжди $€$ підприємствокоординатор, котре займається формуванням вимог проекту, підбором виконавців, їх оцінкою і відбором, розподілом виконавців, відслідковуванням і перерозподілом виконавців і ресурсів по проекту [5, с. 153].

Яскравим прикладом проникнення інформаційних технологій на всі етапи функціонування підприємства (в тому числі і його створення) $€$ програмне забезпечення для створення бізнес-плану. Такі програми можуть не лише прораховувати важливі показники, а й навіть формувати звіти з описом проекту. Особливо актуально це для малого бізнесу, оскільки не всі мають достатньо знань та інформації для самостійного проведення аналізу та правильного розрахунку затрат, вигод та показників прибутковості та інвестиційної привабливості, а замовлення послуги по складанню бізнесплану у спеціалізованих компаній є достатньо дорогим.

В США компанія Palo Alto Software пропонує програму Business Plan Pro, що містить набір заготовок, за допомогою яких можна проводити розрахунки, не потребуючи спеціальних знань чи експертних порад [6, с. 7677]. Більше того, Palo Alto Software надає програмне забезпечення по бізнесплануванню Університету в штаті Орегон, локальним центрам розвитку малого бізнесу, SCORE офісам (некомерційна організація, що займається наставництвом малого бізнесу) [6, с. 76].

В Україні прикладом такої програми є Програмний комплекс «Бізнесплан» (розроблений у Полтавському національному технічному університеті 
імені Юрія Кондратюка) та сайт, на якому містяться відповідні інструкції по роботі з програмою [7].

Поширення таких програм суттєво полегшує організаційні процеси по створенню власного бізнесу, що особливо важливо для України, адже в сучасних умовах особливо важливо підтримувати малий та середній бізнес та сприяти його розвитку.

Використання таких програм можливе і діючими підприємствами, що бажають розширити сферу діяльності, вийти на нові ринки, змінити напрям діяльності, особливо в кризових умовах, коли власники не мають коштів на проведення додаткових досліджень, але при цьому не хоті б згортати повністю діяльність.

Більше того, сьогодні інформаційні технології формують не лише нові зовнішні можливості, а й внутрішні. При цьому мова йде не лише про прискорення обміну інформацією всередині компанії, а й про формування чи підтримку корпоративної культури, розширення можливості комунікації 3 партнерами (постачальниками, підрядчиками чи навіть клієнтами). Це стає можливо завдяки поширенню нових трендів - корпоративного порталу (так званий інтранет) та корпоративних соцмереж.

Корпоративний портал за визначенням спеціалістів - це всі інформаційні ресурси компанії, доступ до яких можливий через Інтернет або мобільний додаток [8]. Це по суті величезна база напрацьованих знань (i формальних, і неформальних), що використовуються всіма співробітниками (в першу чергу) та партнерами, що мають до них доступ. Вона може містити навчальні матеріали (записи вебінарів, конференцій, інформацію щодо спільних проектів, бази клієнтів чи постачальників, результати певних досліджень чи тестів), формувати платформу для спілкування учасників певного проекту чи проведення онлайн-переговорів або мозкових штурмів. Така система формує переваги не лише з точки зору можливості швидкого доступу до потрібної інформації, але і підвищує ефективність роботи компанії. Так, будь-який працівник може протягом кількох хвилин в загальній базі віднайти потрібну інформацію, а не витрачати час на звернення з запитом до відповідного відділу.

Корпоративна соцмережа $є$ менш формальним засобом обміну інформацією, проте в рамках конкретного підприємства вона в першу чергу дозволяє створювати більш згруповану та дружню команду навіть в тому випадку, коли компанія має безліч офісів по світу. По суті це аналог соцмереж, як, наприклад, Facebook, але лише для співробітників компанії. В Україні прикладами успішного впровадження корпоративних соцмереж в бізнес $є$ JTI Ukraine та МТC Україна. 
Можна говорити про те, що інформаційні технології сьогодні зачіпають не лише інформаційну, а й інші складові економічної безпеки підприємства (табл. 1).

Таблиия 1

Вплив інформаційних технологій на економічну безпеку підприємства за складовими

\begin{tabular}{|c|c|c|}
\hline Складова & Позитивний вПлив & Негативний вплив \\
\hline Фінансова & $\begin{array}{l}\text { Економія коштів: на придбання } \\
\text { обладнання, пошук кадрів, } \\
\text { розгортання бізнесу, формування } \\
\text { бізнес-плану, оренду офісу (у } \\
\text { випадку роботи через хмарні } \\
\text { технологіі), виробництво (вико- } \\
\text { ристання онлайн-аутсорсингу). }\end{array}$ & $\begin{array}{ll}\text { Можливість нести фінансові втрати від } \\
\text { загострення } \\
\text { певлайн-конкуренції, втрата } \\
\text { (наприклад, особливий дизайн) через } \\
\text { легкий доступ до нього конкурентів. }\end{array}$ \\
\hline Інтелектуальна & 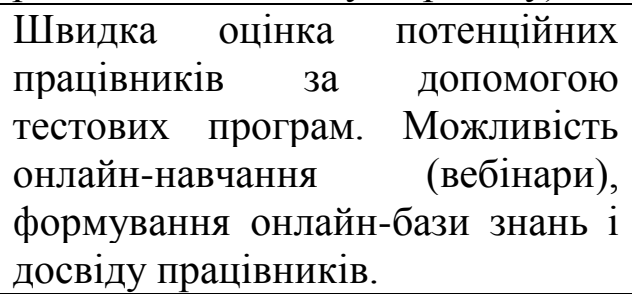 & $\begin{array}{l}\text { У випадку недосконалої кадрової } \\
\text { політики - втрата можливості найняти } \\
\text { висококваліфікованого працівника через } \\
\text { відкритість відгуків про компанію; } \\
\text { ризики розголошення корпоративної } \\
\text { інформації, що присутня в інтранеті }\end{array}$ \\
\hline Кадрова & 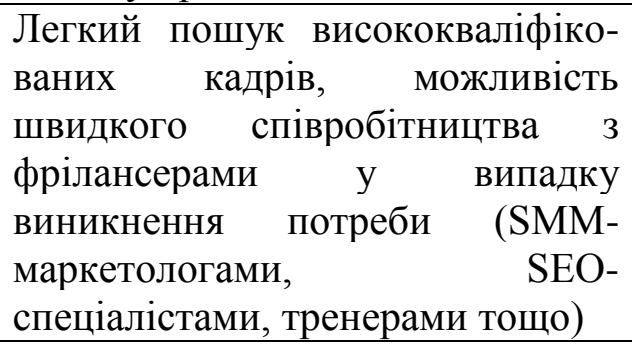 & $\begin{array}{l}\text { Можливість втрати працівників через їх } \\
\text { переманювання конкурентами }\end{array}$ \\
\hline Технологічна & $\begin{array}{l}\text { Полегшення доступу до нових } \\
\text { технологій чи обміну ними; } \\
\text { можливості } \\
\text { партнерам технологічні процеси і } \\
\text { оперативно отримувати готові } \\
\text { продукти, комплектуючі }\end{array}$ & $\begin{array}{l}\text { Втрата переваг через швидке } \\
\text { розповсюдження технології серед інших } \\
\text { учасників ринку }\end{array}$ \\
\hline Інформаційна & $\begin{array}{l}\text { Доступ до інформації, досвіду } \\
\text { видатних тренерів, коучів, } \\
\text { аналітиків; наявність статистич- } \\
\text { ної інформацї̈; швидкий обмін } \\
\text { результатами досліджень серед } \\
\text { всього персоналу компанії; } \\
\text { можливість робити онлайн- } \\
\text { запити до державних установ без } \\
\text { потреби втрачати час на поїздки; } \\
\text { можливість отримати } \\
\text { інформацію про клієнта чи } \\
\text { партнера - від кредитної історії } \\
\text { до судових проваджень }\end{array}$ & $\begin{array}{l}\text { Потреба «фільтрації» та швидкого } \\
\text { аналізу інформації, що постійно } \\
\text { надходить до підприємства; ризик } \\
\text { використати інформацію, що не } \\
\text { пройшла перевірку і є неправильною }\end{array}$ \\
\hline
\end{tabular}


Продовження табл. 1

\begin{tabular}{|c|c|c|}
\hline Ринкова & $\begin{array}{l}\text { Вихід на нові ринки, в тому числі } \\
\text { зарубіжні, без фізичної } \\
\text { присутності }\end{array}$ & $\begin{array}{l}\text { Втрата конкурентних позицій } \\
\text { «власному» ринку через вторгнення до } \\
\text { нього онлайн-конкурентів }\end{array}$ \\
\hline Інтерфейсна & $\begin{array}{l}\text { Швидкість обміну інформацією } 3 \\
\text { контрагентами }\end{array}$ & $\begin{array}{lr}\text { Ризик втратити } & \text { чи випадково } \\
\text { неправильно } & \text { переадресувати } \\
\text { iнформацію } & \\
\end{array}$ \\
\hline Силова & 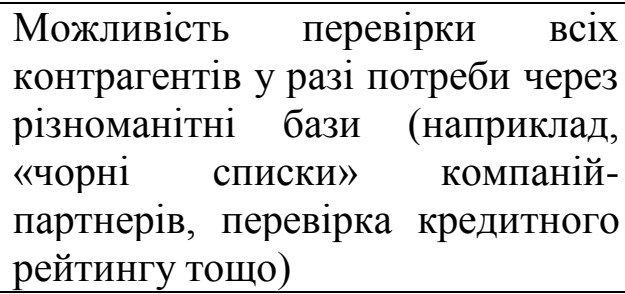 & $\begin{array}{ll}\text { Розширення } \\
\text { підприємство }\end{array}$ \\
\hline Правова & $\begin{array}{lr}\text { Захищеність } & \text { інформації через } \\
\text { використання } \\
\text { технологій }\end{array}$ & $\begin{array}{l}\text { Швидке розповсюдження інформації } \\
\text { про недобросовісні компанії чи дії } \\
\text { окремих її працівників, в тому числі - не } \\
\text { завжди правдивої }\end{array}$ \\
\hline
\end{tabular}

Складено авторами на основі [9]

3 даної таблиці можна побачити, що ступінь проникнення сучасних технологій в бізнес $є$ настільки глибоким, що не обмежується лише інформацією, а й впливає на інші елементи діяльності підприємства, впливаючи в загальному на економічну безпеку в цілому. А тому перед менеджерами постають додаткові завдання по контролю рівня економічної безпеки з урахуванням сучасних тенденцій.

Висновки. Розвиток інформаційних технологій сьогодні дозволяє не лише полегшити роботу персоналу та керівництва, а й удосконалити діяльність підприємства в цілому, сформувати нові можливості, підвищити ефективність роботи окремого працівника та персоналу взагалі. Вплив інформаційних технологій присутній на всіх етапах діяльності підприємства від бізнес-планування до зміни напряму діяльності.

Більше того, вони дозволили створювати онлайн-підприємства, які іноді або не присутні в країні, де розташований їх ринок збуту, або взагалі можуть існувати лише в Інтернет-просторі.

Можна говорити про те, що вплив інформаційних технологій несе як можливості, так і нові ризики, які потрібно оцінювати і враховувати сучасному керівнику.

Наукова новизна полягає у подальшому розвитку теоретичних положення щодо оцінювання позитивного та негативного впливу сучасних інформаційних технологій на економічну безпеку підприємства за іi складовими.

Практичне значення роботи полягає у формуванні теоретичної бази, яка може використовуватися при формуванні нових принципів управління та побудові механізму забезпечення економічної безпеки підприємства, котрі 
брали б до уваги дестабілізуючі впливи з метою попередження негативних наслідків.

Напрямки подальших досліджень полягають у визначенні методів управління економічною безпекою та формуванні відповідного механізму, які враховували б можливі ризики від проникнення інформаційних технологій у всі сфери діяльності підприємства.

\section{Література:}

1. Каркавчук В., Черчук А. Оптимізація управління інформаційною безпекою підприємства / В.Каркавчук, А.Черчук // Проблеми становлення інформаційної економіки в Україні: Матеріали Міжнародної науково-практичної конференції «Проблеми становлення інформаційної економіки в Україні». - Львів: Ліга-Прес, 2015. - с. 190-191 .

2. Орлик О. В. Інформаційні технології управління готелями / О. В. Орлик, Ю. С. Лужанська // Інформатика та інформаційні технології: студ. наук. конф., 20 квітня 2015 р. : матер. конф. - Одеса: ОНЕУ, 2015. - С. 12-15.

3. Рудковський О. Які ж насправді переваги надає «хмара» порівняно із десктопними додатками? [Електронне джерело] - Режим доступу: http://www.business.ua/opinions/khmarn_tekhnolog_dlya_b_znesu-268935/

4. Сайт Торгово-промислової палати України [Електронне джерело]. - Режим доступу: http://www.ucci.org.ua/visti/ukr/news/2016/11/17/40_.shtml

5. Рамазанов С.К., Степаненко О.П., Тимашова Л.А. Р 21 Методи антикризового управління. Монографія. - Луганськ: Вид-во СНУ ім. В. Даля, 2004. - 192 с.

6. Клінцов Л. М. Інформаційні системи та технології для створення бізнес-планів малих підприємств / Л. М. Клінцов, М. В. Міщенко // Науковий вісник Полісся. — 2016. — №1 (5). - C. 74-78

7. Головна сторінка сайту інтернет-підтримки ПК «Бізнес План» [Електронне джерело]. Режим доступу: https://sites.google.com/site/bisnesplanpoltntu/

8. Анна Кравець Навіщо потрібна корпоративна соцмережа і як іiі створити? [Електронне джерело]. - Режим доступу: http://forbes.net.ua/ua/explain/management_and_staff/1375370navishcho-potribna-korporativna-socmerezha-i-yak-yiyi-stvoriti

9. Колешня Я.А. Особенности оценки экономической безопасности малих и средних предприятий / Я.А. Колешня // Fundamental and applied sciences today VIII: Proceedings of the Conference. North Charleston, 10-11.05.2016, Vol.2 - North Charleston, SC, USA:CreateSpace, 2016, p. 159 